\title{
FLUORESCENCE IN SITU HYBRIDIZATION ANALYSIS OF CHROMOSOMAL LOCALIZATION OF THREE HUMAN CYTOCHROME P450 2C GENES (CYP2C8, 2C9, AND 2C10 $)$ AT 10q24.1
}

\author{
Kiyoshi Inoue, ${ }^{1, *}$ Johji Inazawa, ${ }^{2}$ Yasuhiko Suzuki, ${ }^{1}$ \\ Tsutomu Shimada, ${ }^{1}$ Hiroshi Yamazaki, ${ }^{1}$ F. Peter Guengerich, ${ }^{3}$ \\ and Tatsuo $\mathrm{ABE}^{2}$ \\ ${ }^{1}$ Osaka Prefectural Institute of Public Health, Nakamichi, Higashinari-ku, Osaka 537, Japan \\ ${ }^{2}$ Department of Hygiene, Kyoto Prefectural University of Medicine, \\ Kamigyo-ku, Kyoto 602, Japan \\ ${ }^{3}$ Department of Biochemistry and Center in Molecular Toxicology, Vanderbilt University \\ School of Medicine, Nashville, TN 37232, U.S.A.
}

Summary Chromosomal localization of three human cytochrome P450 genes belonging to the CYP2C subfamily (CYP2C8, 2C9, and 2C10) was identified by fluorescence in situ hybridization (FISH). An original MP-8 clone was used as a DNA probe for the assignment of the CYP2C10 gene, while two cDNA probes, a $1.37 \mathrm{~kb}$ fragment of CYP2C8 and a 1.19 $\mathrm{kb}$ fragment of $\mathrm{CYP} 2 \mathrm{C}$, were obtained after amplifying the predicted fragments (MP-20 and MP-4 clones, respectively) by polymerase chain reaction using a single human liver cDNA library. The results showed that three human $\mathrm{CYP} 2 \mathrm{C} 8,2 \mathrm{C}$, and $2 \mathrm{C} 10 \mathrm{cDNAs}$ were located at the same subchromosomal region, 10q24.1.

Key Words fluorescence in situ hybridization, CYP2C subfamily, chromosome 10 , chromosomal localization, polymerase chain reaction

Received March 17, 1994; Revised version accepted June 27, 1994.

*To whom correspondence should be addressed.

TThe coding sequences of the genes termed CYP2C9 and CYP2C10 differ in only two amino acids, 358 and 417 (Ged et al., 1988; Srivastava et al., 1991). The CYP2C10 sequence corresponds to the first cDNA we isolated from this family (Umbenhauer et al., 1987). We reported that the two cDNAs now termed 2C9 (MP-4) and 2C10 (MP-8) differed considerably in their $3^{\prime}$ non-coding sequences, and oligonucleotide probes were used to identify both groups of sequences in the mRNA of a single liver sample (Ged et al., 1988). It is conceivable that the existence of the two cDNA clones (within an expression library generated from a single individual) is an artifact of the library construction, or that the sequences recognized by the probes are parts of other genes. Nevertheless, P450 2C9 and P450 2C10 are treated here as the products of individual genes. When proteins purified from the liver are considered here, they are designated P450 2C9/10 because no amino acid sequence analysis was done in the regions where differences occur (Ged et al., 1988; Srivastava et al., 1991). 


\section{INTRODUCTION}

The human liver microsomal cytochrome P450 (P450) enzymes encoded by the CYP2C subfamily are known to catalyze the oxidation of mephenytoin and to exhibit genetic polymorphism of metabolism in humans (Wedlund et al., 1984; Kupfer and Preisig, 1984). Shimada et al. (1986) first isolated two similar forms of human liver P450 enzymes responsible for $(S)$-mephenytoin 4-hydroxylation, termed P-450 $0_{M_{-1}}$ and P-450 $\mathrm{MP}_{-2}$. Furthermore, Umbenhauer et al. (1987) and Ged et al. (1988) have isolated four cDNA clones that contained nearly full-length DNA sequences, from a bacteriophage $\lambda \mathrm{gt} 11$ library prepared from a single human liver using anti-P450 ${ }_{12-1}$ as a probe, and designated them as MP-12 (CYP2C8), MP-20 (CYP2C8), MP-4 (CYP2C9), and MP-8 (CYP2C10). Recently, CYP2C9 and CYP2C10 enzymes have been reported to catalyze tolbutamide methyl hydroxylation and hexobarbital 3'-hydroxylation (Brian et al., 1989; Srivastava et al., 1991; Yasumori et al., 1991), and CYP2C8 enzyme is found to be one of the benzo(a)pyrene 3-hydroxylases (Yun et al., 1992). Although the human P450 gene(s) encoding the CYP2C subfamily was mapped to $10 \mathrm{q} 24.1-10 \mathrm{q} 24.3$ by a panel of human-rodent somatic cell hybrids and isotopic in situ hybridization (Okino et al., 1987; Riddell et al., 1987; Meehan et al., 1988), the exact localization of this multigene family remains unclear.

In the present study, we mapped the human CYP2C subfamily genes (CYP2C8, $2 \mathrm{C} 9$, and $2 \mathrm{C10}$ ) by fluorescence in situ hybridization (FISH) combined with replication R-bands on prometaphase chromosomes (Inoue et al., 1992). An original MP-8 clone was used as a DNA probe to assign the CYP2C10 gene. A $1.37-\mathrm{kb}$ and a $1.19-\mathrm{kb}$ fragment of CYP2C8 and 2C9 respectively, were amplified separately from the liver cDNA library by the polymerase chain reaction (PCR) and subcloned into the pBluescriptIIKS(+) vector. The amplified products were confirmed by DNA sequencing, and used to assign the chromosomal localization by FISH.

\section{MATERIALS AND METHODS}

Synthesis of oligonucleotide primers and PCR (CYP2C8 and 2C9). In order to obtain the CYP2C cDNA probes, two CYP2C cDNAs corresponding to clones MP-20 (CYP2C8) and MP-4 (CYP2C9) were amplified from a liver cDNA library by PCR. Oligonucleotide (20-mer) primers were chemically synthesized on an Applied Biosystems 380A DNA synthesizer (Foster City, CA) using cyanoethyl phosphoramidite chemistry according to the published CYP2C8 and CYP2C9 cDNA sequences (Brian et al., 1989; Ged et al., 1988). After detritylation and alkaline deprotection, the crude material was used for all applications without further purification. Primer pairs from CXP2C8 CDNA included: 5'-TCGAAGC- 
TTTTTTCACTCTGGAGACAGAG-3' and 5'-TCCCTGCAGAGTGACCTGAACAACTCTCC-3', positions 19 to 38 of the CYP2C 8 cDNA plus a HindIII cleavage site (underlined) and positions 1607 to 1588 plus a Pst I cleavage site (underlined), respectively. For the CYP2C9 cDNA, we used: 5'-GCAGTTAACATTTTGGGATGGGGAAGAGG-3 ${ }^{r}$ and 5'-ACCGGTACCAATGTGAGATGACAGGTGAG3', positions 77 to 96 plus a $H p a l$ cleavage site (underlined) and positions 1263 to 1244 plus a $K p n I$ cleavage site (underlined). PCR (Saiki et al., 1985) was performed with $200 \mathrm{ng}$ DNA (liver cDNA library), $2.5 \mu \mathrm{l}$ each of oligonucleotide primer $(20 \mu \mathrm{M}), 10 \mu \mathrm{l}$ of $1 \mathrm{~mm}$ dNTPs, $5 \mu \mathrm{l}$ of $10 \times$ PCR buffer and $1 \mathrm{U}$ Taq DNA polymerase in a final volume of $50.4 \mu \mathrm{l}$ (ATTO Zymoreactor AB-1800). The reaction was performed under the following conditions: denaturation at $92^{\circ} \mathrm{C}$ for $1 \mathrm{~min}$, annealing at $55^{\circ} \mathrm{C}$ for $1 \mathrm{~min}$, and extension at $72^{\circ} \mathrm{C}$ for $2 \mathrm{~min}$. After 35 cycles of amplification, the products underwent a final extension at $72^{\circ} \mathrm{C}$ for $5 \mathrm{~min}$. A portion of each sample $(1 \mu l)$ was analyzed by electrophoresis through a $1 \%$ agarose gel containing $1 \mu \mathrm{g} / \mathrm{ml}$ ethidium bromide.

Subcloning and sequencing of the PCR products (CYP2C8 and 2C9). According to the restriction sites of the primers, the amplified DNA fragments by PCR were digested with HindIII and PstI in CYP2C8 and KpnI and HpaI in CYP2C9, respectively. The PCR products from $\mathrm{CYP} 2 \mathrm{C} 8$ and $\mathrm{CYP} 2 \mathrm{C} 9$ were ligated with the pBluescriptIIKS(+) vector and transformed into Escherichia coli strain XL-1 using a Gene Pulser apparatus for the electro-transformation E. coli (Bio-Rad). The transformants were selected on agar plates containing ampicillin $(50 \mu \mathrm{g} / \mathrm{ml})$ and X-Gal/IPTG. The $1.37 \mathrm{~kb}$ fragment of CYP2C8 was subcloned into the HindIII and Pst I sites of pBluescriptIIKS $(+)$, and the $1.19 \mathrm{~kb}$ fragment of CYP2C9 was subcloned into the KpnI and SmaI sites of pBluescriptIIKS $(+)$. These fragments were sequenced using the AutoRead ${ }^{T M}$ Sequencing kit according to the directions of the supplier (Pharmacia, Uppsala, Sweden).

Subcloning of CYP2C10. An M13 phage containing the original MP-8 cDNA described by Brian et al. (1989) was infected with $E$. coli JM103. The collected phage DNA was digested with $E c o$ RI and the resulting fragment $(1.6 \mathrm{~kb})$ was subcloned into the plasmid vector pUC119 as described by Brian et al. (1989).

Chromosome preparation and fuorescence in situ hybridization. Metaphase chromosome spreads were obtained from normal human lymphocyte cultures and synchronized with thymidine as previously described (Viegas-Pequignot and Dutrillaux, 1978; Inoue et al., 1992). R-banding was induced by treating cultures with 5-bromodeoxyuridine (BrdU) during the late S-phase. Slides were aged 1-2 days, baked at $65^{\circ} \mathrm{C}$ for at least $3 \mathrm{~h}$, and kept at $-20^{\circ} \mathrm{C}$ until use.

FISH was performed according to a method recently described for high-resolution mapping of single-copy small genes directly on banded chromosomes (Inazawa et al., 1991; Lemieux et al., 1992; Takahashi et al., 1992; Inoue et al., 1992). Briefly, chromosomes were denatured in $70 \%$ formamide in $2 \times \mathrm{SSC}(1 \times$ $\mathrm{SSC}$ is $0.15 \mathrm{~m}$ sodium chloride/0.015 $\mathrm{m}$ sodium citrate, $\mathrm{pH} 7$ ) at $70^{\circ} \mathrm{C}$ for $2 \mathrm{~min}$ 
followed by dehydration in ethanol. The CYP2C8 cDNA probe (containing the 1.37-kb cDNA fragment cloned into pBluescriptIIKS $(+))$, the CYP2C9 cDNA probe (containing the 1.19-kb cDNA fragment cloned into pBluescriptIIKS $(+)$ ) and a CYP2C10 cDNA probe $(1.6 \mathrm{~kb})$ were labeled by nick translation using biotin-16-dUTP (Boehringer, Mannheim) for $1.5 \mathrm{~h}$ at $15^{\circ} \mathrm{C}$. The biotinylated probes were denatured at $75^{\circ} \mathrm{C}$ for $10 \mathrm{~min}$. The probe concentration on the slides was $500 \mathrm{ng}$ in $10 \mu \mathrm{l}$ of the hybridization mixture $(50 \%$ formamide, $10 \%$ dextran sulfate, $2 \times \mathrm{SSC}$, and $10 \%$ bovine serum albumin). Hybridization proceeded for $16-18 \mathrm{~h}$ at $37^{\circ} \mathrm{C}$. After being washed with $50 \%$ formamide $/ 2 \times \mathrm{SSC}, 2 \times \mathrm{SSC}$, and $1 \times \mathrm{SSC}$ for $37^{\circ} \mathrm{C}$ for $15 \mathrm{~min}$ each, the slides were treated with $4 \%$ Block Ace ${ }^{T M}$ (Dainippon Pharmaceutical, Osaka) at $42^{\circ} \mathrm{C}$ for $10 \mathrm{~min}$ to block fluorochrome background noise. We detected small single-copy genes (1.37-kb insert in CYP2C8 cDNA, $1.19-\mathrm{kb}$ insert in CYP2C9 cDNA, and $1.6-\mathrm{kb}$ insert in CYP2C10 cDNA), by amplification with avidin-conjugated fluorescein isothiocyanate (FITC-avidin) (Boehringer, Mannheim) and a biotinylated anti-avidin antibody (Vector, Burlingame, CA) (Pinkel et al., 1986; Inoue et al., 1992). Finally, the chromosomes were stained with propidium iodide ( $1 \mu \mathrm{g} / \mathrm{ml}$, Sigma, St. Louis, MO). Slides were mounted with a fluorescence anti-fade solution containing $1 \%$ DABCO (1,4-diazabicyclo[2,2,2]octane, Sigma) and observed under a fluorescence microscope (filter combinations: B-2A, excitation $450-490 \mathrm{~nm}$, barrier $520 \mathrm{~nm}$; B-2E, excitation $450-490 \mathrm{~nm}$, barrier $520-560 \mathrm{~nm}$ ). The G-banding pattern on the same metaphase was delineated by means of a different filter combination (UV-2A, excitation 400 $440 \mathrm{~nm}$, barrier $470 \mathrm{~nm}$ ). Photographs were taken using Fujichrome 400D film (800 ASA).

\section{RESULTS AND DISCUSSION}

CYP2C8 and CYP2C9 cDNAs (Ged et al., 1988) from a human liver cDNA library were amplified by PCR. The primer pairs, positions 19 to 38 and 1607 to 1588 were selected to amplify a $1589 \mathrm{bp}$ region of CYP2C8 and those from positions 77 to 96 and 1263 to 1244 of 1187 bp of CYP2C9 were also used. The product of $\mathrm{CYP} 2 \mathrm{C} 9$ yielded fragments of the expected size. However, that of CYP2C8 was $1.37-\mathrm{kb}$ long because of a $P_{s t} \mathrm{I}$ site at position 1383 . In order to confirm the CYP2C8 and CYP2C9 sequences in the amplified cDNA fragments, the fragments were subcloned into the vector pBluescriptIIKS $(+)$. The nucleotide sequences obtained from the subclones showed complete identity with the corresponding published sequences (Ged et al., 1988).

We performed FISH mapping using these biotin-labeled probes to assign the human CYP2C gene location. The procedure allows the simultaneous identification of the G-banded chromosome pattern and hybridization signals on the same metaphase preparation by simply changing the filters (filter combination B-2A and UV-2A, Nikon). A detailed distribution analysis showed that the hybridization 


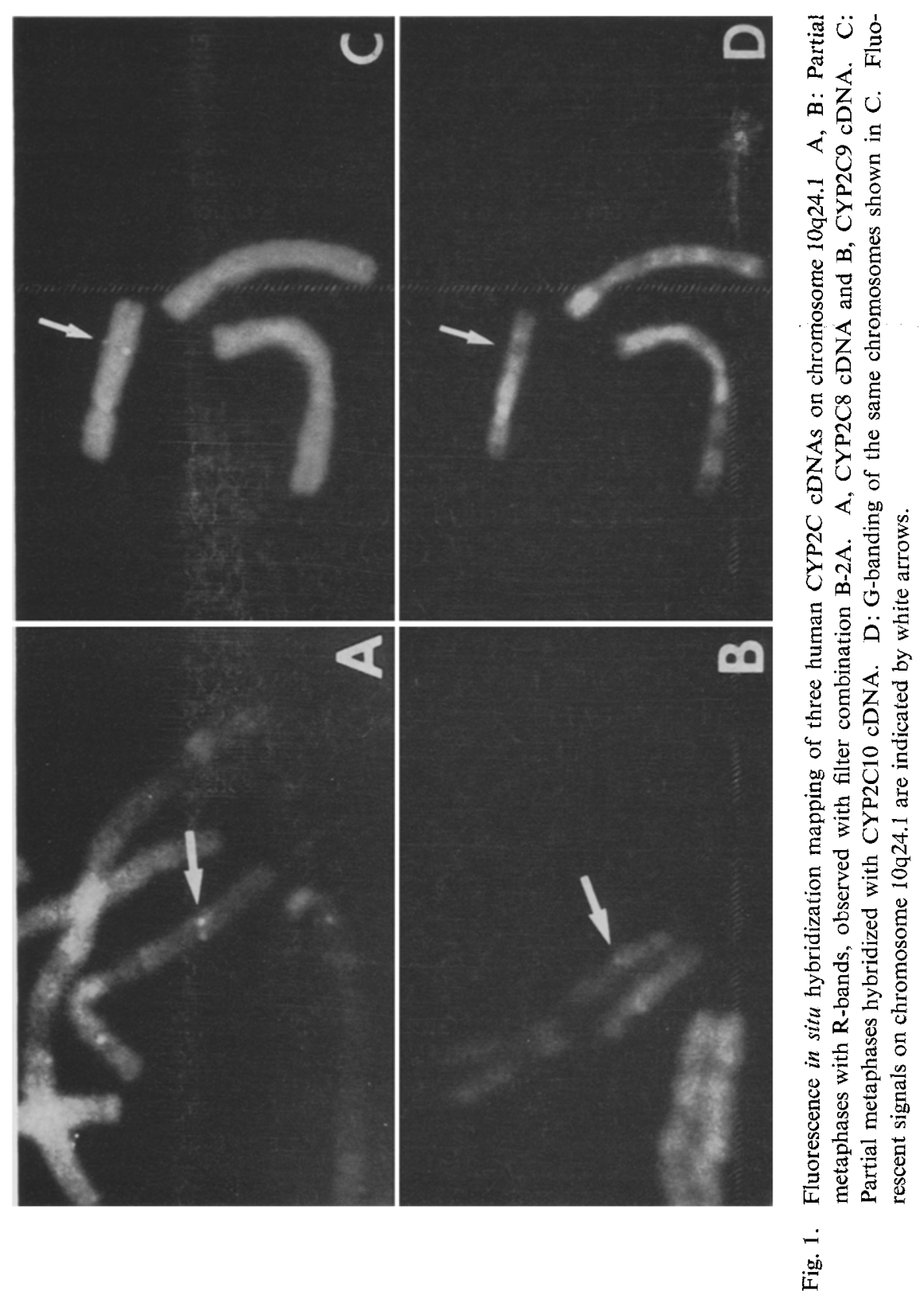

Vol. 39, No. 3, 1994 
site in the three probes was the same: 10q24 (Fig. 1). Among 100 metaphases examined with the CYP2C8 probe, $12(12 \%)$ exhibited double fluorescent signals on only one of the chromatids. One hundred metaphases were also examined with CYP2C9 and CYP2C10 cDNA probes. Five (5\%) and two $(2 \%)$, respectively, of the metaphases exhibited complete symmetrical double fluorescent signals on both chromatids. Sixteen cells for CYP2C9 and 17 for CYP2C10 showed either single or double fluorescent signals on each chromatid. None of the other chromosomes showed consistent fluorescent signals in these probes. We further examined the localization of the CYP2C8, 2C9, and 2C10 cDNAs in the 10q24 region. For CYP2C8, the signals were observed in the following location; $8.7 \%$ at $10 \mathrm{q} 23.3$, $82.6 \%$ at $10 \mathrm{q} 24.1$, and $8.7 \%$ at $10 \mathrm{q} 24.2$, respectively. CYP2C9 signals were observed in $86.0 \%$ at $10 \mathrm{q} 24.1,6.0 \%$ at $10 \mathrm{q} 24.2$, and $8.0 \%$ at $10 \mathrm{q} 24.3$. CYP2C10 signals were found in $4.5 \%$ at $10 \mathrm{q} 23.3,72.2 \%$ at $10 \mathrm{q} 24.1,18.2 \%$ at $10 \mathrm{q} 24.2$, and $4.5 \%$ at $10 \mathrm{q} 24.3$, respectively. Thus, the localization of the three CYP2C cDNA examined was on human chromosome $10 \mathrm{q} 24.1$.

At present, 11 families comprising 19 subfamilies are known in the human cytochrome P450 gene superfamily, of which 17 have been mapped in the human genome (Nelson et al., 1993). The human chromosome localization of the human P450 gene encoding the CYP2C subfamily has been reported by investigators from three different laboratories. Okino et al. (1987) using a panel of human-rodent somatic cell hybrids, have assigned the human P450 1 cDNA (designated Hpl-1), which is nealy identical with clone MP-20 (CYP2C8), to human chromosome 10. Riddell et al. (1987) and Meehan et al. (1988) using both somatic cell hybridization and isotopic in situ hybridization have also assigned the CYP2C9 to 10q24.1-10q24.3. Our results obtained by FISH mapping of CYP2C8, 2C9, and $2 \mathrm{C} 10 \mathrm{cDNAs}$ confirmed the previous studies, further suggest that the genes for members of the CYP2C subfamily lie on a limited region of human chromosome 10 at q24.1.

\section{REFERENCES}

Brian WR, Srivastava PK, Umbenhauer DR, Lloyd RS, Guengerich FP (1989): Expression of a human liver cytochrome P-450 protein with tolbutamide hydroxylase activity in Saccharomyces cerevisiae. Biochemistry 28: 4993-4999

Ged C, Umbenhauer DR, Bellew TM, Bork RW, Srivastava PK, Shinriki N, Lloyd RS, Guengerich FP (1988): Characterization of cDNAs, mRNAs, and proteins related to human liver microsomal cytochrome P-450 (S)-mephenytoin 4'-hydroxylase. Biochemistry 27: 6929-6940

Inazawa J, Fukunaga R, Seto Y, Nakagawa H, Misawa S, Ate T, Nagata S (1991): Assignment of the human granulocyte colony-stimulating factor receptor gene (CSF3R) to chromosome $\mathrm{l}$ at region $\mathrm{p} 35-\mathrm{p} 34.3$. Genomics 10: 1075-1078

Inoue $\mathrm{K}$, Inazawa J, Nakagawa $\mathrm{H}$, Shimada T, Yamazaki H, Guengerich FP, Abe T (1992): Assignment of the human cytochrome P-450 nifedipine oxidase gene (CYP3A4) to chromosome 7 at band $\mathrm{q} 22.1$ by fluorescence in situ hybridization. Jpn J Human Genet 37: 133-138

Kupfer A, Preisig R (1984): Pharmacogenetics of mephenytoin: a new drug hydroxylation polymorphism in man. Eur $\mathbf{J}$ Clin Pharmacol 26: 753-759 
Lemieux N, Dutrillaux B, Viegas-Pequignot E (1992): A simple method for simultaneous R- or G-banding and fluorescence in situ hybridization of small single-copy genes. Cytogenet Cell Genet 59: 311-312

Meehan RR, Gosden JR, Rout D, Hastie ND, Friedberg T, Adesnik M, Buckland R, Heyningen V van, Fletcher J, Spurr NK, Sweeney J, Wolf CR (1988): Human cytochrome P-450 PB-1: A multigene family involved in mephenytoin and steroid oxidations that maps to chromosome 10. Am J Hum Genet 42: 26-37

Nelson DR, Kamataki T, Waxman DJ, Guengerich FP, Estabrook RW, Feyereisen R, Gonzalez FJ, Coon MJ, Gunsalus IC, Gotoh O, Okuda K, Nebert DW (1993): The P450 superfamily: update on new sequences, gene mapping, accession numbers, early trivial names of enzymes, and nomenclature. DNA Cell Biol 12: 1-51

Okino ST, Quattrochi LC, Pendurthi UR, McBride OW, Tukey RH (1987): Characterization of multiple human cytochrome P-450 1 cDNAs. The chromosomal localization of the gene and evidence for alternate RNA splicing. J Biol Chem 262: 16072-16079

Pinkel D, Straume T, Gray JW (1986): Cytogenetic analysis using quantitative, high-sensitivity, fluorescence hybridization. Proc Natl Acad Sci USA 83: 2934-2938

Riddell DC, Wang H, Umbenhauer DR, Beaune PH, Guengerich FP, Hamerton JL (1987): Regional assignment for the genes encoding human P450IIIA3 (CYP3) and P450IIC9 (CYP2). Cytogenet Cell Genet 46: 682

Saiki RK, Scharf S, Faloona F, Mullis KB, Horn GT, Erlich HA, Arnhemim N (1985): Enzymatic amplification of $\mathrm{b}$ globulin genomic sequences and restriction site analysis for diagnosis of sickle cell anemia. Science 230: 1350-1354

Shimada T, Misono KS, Guengerich FP (1986): Human liver microsomal cytochrome P-450 mephenytoin 4-hydroxylase, a prototype of genetic polymorphism in oxidative drug metabolism. J Biol Chem 261 : 909-921

Srivastava PK, Yun C-H, Beaune PH, Ged C, Guengerich FP (1991): Separation of human liver tolbutamide hydroxylase and $(S)$-mephenytoin $4^{\prime}$-hydroxylase cytochome P450 enzymes. Mol Pharmacol 40: 69-79

Takahashi E, Ayusawa D, Kaneda S, Itoh Y, Seno T, Hori T (1992): The human ubiquitin-activating enzyme E1 gene (UBE1) mapped to band Xp11.3 $\rightarrow$ p11.23 by fluorescence in situ hybridization. Cytogenet Cell Genet 59: 268-269

Umbenhauer DR, Martin MV, Lloyd RS, Guengerich FP (1987): Cloning and sequence determination of a complementary DNA related to human liver microsomal cytochrome P-450 $S$-mephenytoin 4-hydroxylase. Biochemistry 26: 1094-1099

Viegas-Pequignot E, Dutrillaux B (1978): Une methode simple pour obtenir des prophases et des prometaphases. Ann Gene (Paris) 21: 122-124

Wedlund PJ, Aslanian WS, McAllister CB, Wilkinson GR, Branch RA (1984): Mephenytoin hydroxylase deficiency in Caucasians: frequency of a new drug oxidative drug metabolism polymorphism. Clin Pharmacol Ther 36: 773-780

Yasumori T, Yamazoe Y, Kato R (1991): Cytochrome P-450 human-2 (P-450IIC9) in mephenytoin hydroxylation polymorphism in human livers. Differences in substrate and stereoselectivities among microheterogenous P-450IIC species expressed in yeast. J Biochem (Tokyo) 109: 711717

Yun CH, Shimada T, Guengerich FP (1992): Roles of human liver cytochrome P4502C and 3A enzymes in the 3-hydroxylation of benzo(a)pyrene. Cancer Res 52: 1868-1874 